\title{
Learning Model of Entreupreuneurship Using Business Incubator Based on Web 2.0 Technology
}

\author{
R. Hurriyati, Lisnawati, Sulastri \\ Faculty of Economic and Business Education, \\ Indonesia University of Education, \\ Bandung, Indonesia \\ ratih@upi.edu
}

\author{
Y. Rosmansyah \\ School of Electrical Engineering and Informatics, \\ Bandung Institute of Technology, \\ Bandung, Indonesia \\ yusep@stei.itb.ac.id
}

\begin{abstract}
Indonesian youth unemployment rates are among the highest when compared with other countries. Unemployed youth in Indonesia reached $\mathbf{2 5 . 1}$ percent of the total workforce. Therefore, there must be a serious effort to reduce the unemployment rate. Learning Model entrepreneurship through business incubators 2.0 is a web-based technology to provide solutions to the problems of educated unemployment realists in Indonesia, which reached $41.8 \%$ of total national unemployment, of which $12.78 \%$ came from universities. The methodology used is done with an experimental approach, which prioritizes the participation of students through the business incubator based on web 2.0 technologies developed through four phases, namely Phase Process Understanding Entreupreneurial, Stage being The Entreupreuneur, be the entrepreneur Phase, and Phase Scale Up. The fourth stage is carried out through 16 times personally consisting of Creativity Program, foundation program, Entrepreneurship Program, Hatching Program, The results showed as many as 174 students who participated via web-based business incubator $\mathbf{2 . 0}$, which managed to reach the hatchery program only 43 students or $25 \%$, and 95 students can achieve entrepreneurial program or $55 \%$. This finding shows to be entrepreneurial, can be realized through a learning model of web-based business incubators 2.0. Through this model, there is the interaction between students, faculty, business practitioners, with the concept of easier and flexible.
\end{abstract}

Keywords: Business Incubator, Web 2.0 Technology, Learning Model of Entrepreneurship

\section{INTRODUCTION}

The amount of unemployed young generation people reach $41.81 \%$ from total unemployment in Indonesia in 2015.The percentage of unemployment category that listed from university's graduated, high school, junior school, and basic school are: $12.78 \%, 11.9 \%, 7.4 \%, 3.8 \%$. Unemployed university's graduated is the highest (Muh Abud Musa'ad, 2012). Young unemplomentd is high in Indonesia compared to others countries. In 2015, (the number is $25.1 \%$ from total labor force in Indonesia. This problem should be handled seriously.
According to David McClelland [1], to be a developed country, the number of entrepreneur should $2 \%$ or more from the total of population. This threshold needed as a part of all system in the country. Today, Indonesia has only 450,000 entrepreneurs or equivalent to $0.18 \%$ from the total population. US, Singapore, or Malaysia condition is better than Indonesia. Indonesia government has started many initiatives, such as: training for entrepreneurship, incubator, internship, or partnership. Since 2012, the number of entrepreneur is increased up to $3,744,000$ [2]. Hopefully it will be increased more in following years.

In the Directorate of Higher Education's strategic plan, its stated that university should have an initiatives to reach $20 \%$ of their graduated to be entrepreneur, $50 \%$ get jobs in Indonesia, $10 \%$ get jobs abroad, and $10 \%$ continue to the higher level of study. The target for entrepreneurship is very challenging goal.

\section{RESEARCH QUESTION}

Conventional initiatives should be conducted continually. In other hand, more innovative initiative is needed also. Society was changed, so new approaches should be conducted for new generation of young people that have new characteristic. Go back to the facts that the number of graduated unemployed is the highest, innovative initiatives should be focused to the students in university. They should have enough knowledge and learning experiences about how to do entrepreneurship.

This situation raised the interesting research question. What kind of model or initiative can be conducted that in one, side can potentially create a new entrepreneur, also in other sides relevant to the character of young generation. Related to that, there should be innovations in teaching at the University, which is developing and implementing learning that can foster the ability to entrepreneurship 


\section{LITERATURE REVIEW}

Entrepreneurship education is the education that develops and increases students' basic competency for starting an enterprise [3]. Therefore, the purpose of learning, to increase of the interest and competence of entrepreneurship in students. Where to Make learners have the ability to entrepreneurship. Not enough armed only with the knowledge gained through the material in the subjects of entrepreneurship, but the learning process undertaken must lead to Efforts to establish competence and entrepreneurship.

Figure 1 shows the design model of entrepreneurship education program, development from the level of Ontology which is a component of the design of entrepreneurship development to produce educated entrepreneurs.

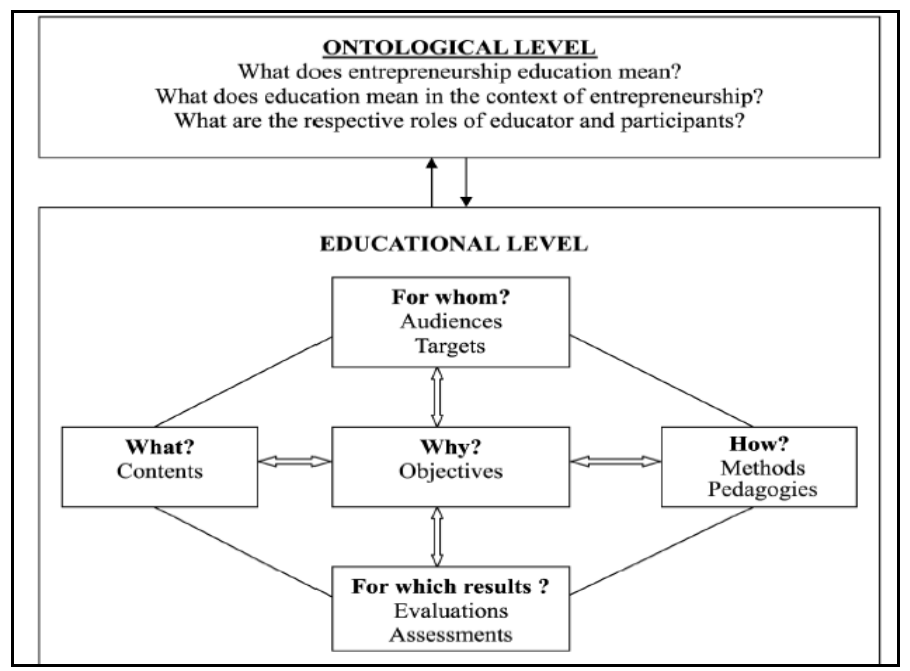

Source: Alain Foyell [4]

Figure 1. Component Design Development of entrepreneurship education

Model approaches [5], adapted by the prototype model of business incubator web 2.0 is a model of entrepreneurship education can produce educated entrepreneurs, for more details can be seen in figure 2 below.

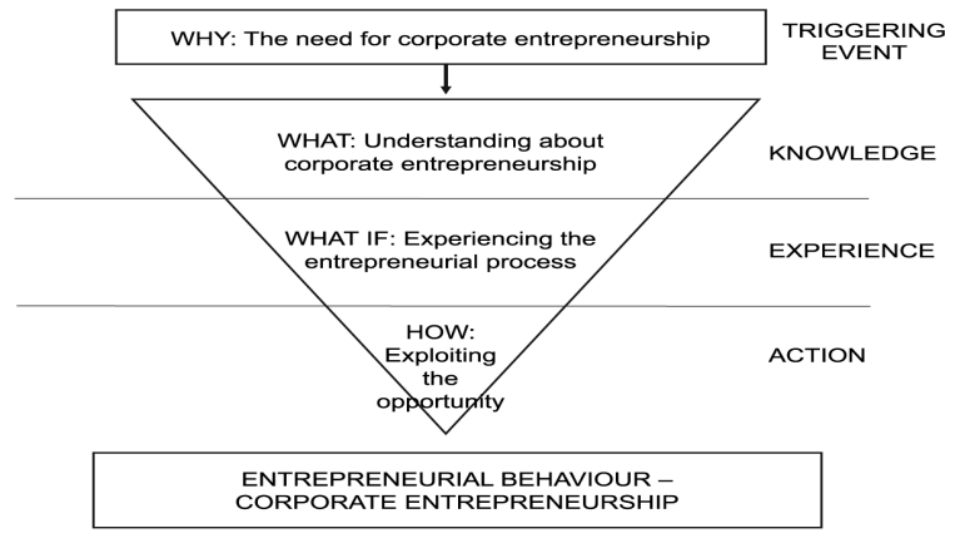

Source: Heinonen, Jarna. [6].

Figure 2. Learning Approach Entrepreneurship In Higher Education
As for the design of learning resource's component for the development of entrepreneurial competencies applied in business incubators web 2.0 , is the design of entrepreneurial learning resources are taken from LJ Edwards and EJ Muir University of Glamorgan is modified by D Rae.

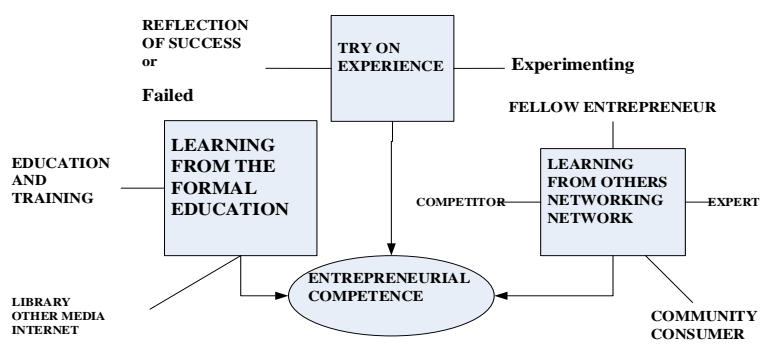

Figure .3 Entrepreneurial learning resources

Source needs of entrepreneurial development can be grouped into three, namely.:

a. Experience with actively trying, with the method of experiential learning (David Kolb) to learn from the experience and capabilities necessary process of reflection experience or reflection (reflective observation), then formulate and conclude (abstract conceptualization) conducts tests on what is inferred (active experimentation ) and back to the events experienced (concreate experience)

b. Networking as a source of learning with others, learning resource's social networks available in large quantities, starting with involving the formulation of business ideas, creation of value offered, product dehu[velopment, product testing, and feed business launch, during the counseling process with a program facilitator and mentor aspects above aspect is part of enriching learning resources from social networking media.

c. The formal process sources with knowledge of entrepreneurship and basic research from official sources

Prototype proposed by Gibb (1999) [9] as follows:

- Understanding Stages Entreupreneurial Process, the first stage is intended that students in-depth understanding of business processes. Starting from the ability to identify and translate business opportunities into value-added superior (WOW effect), how it transformed the added value in the form of products or services and can be consumed by the target customers as well as improved

- The stages being Entreupreuneur, at this stage intended to allow students to learn how one entrepreneur running his business. Beginning with the creation of a business plan to convince a third party in order to fund his business. It committed to what you want to achieve in the future so it is always looking for ways to achieve that goal. A partnership with a third party or sell some or all the ownership. So that through this simulation students are expected to feel the process to become entrepreneurs 
- Be the entrepreneur stage, at this stage the students feel to be an entrepreneur. Starting to determine the added value of the product concept and business concept, then the concept is tested through the test product, test alpha, beta test to reduce the risk of failure and the search for venture capital. Furthermore, they are required to maximize capital entrepreneurship through competency groups, where access to funding and social capital comes from the closest family and friends, so that the risk of failure when business started can be minimiz

- It stages Scale Up is the process of strengthening the business forward, at this stage, aided by an incubation scheme can aid in the form of the process to obtain a patent, business entities, virtual office facilities.

\section{METHODOLOGY}

The methodology consists of several following steps.

1) Define requirements. This first step try to define the requirement that describe the model or solution to be find.

2) Literature Review. The main activities in this second step is finding as much as possible up-to-date research result that related to this research goal. At this research also review related technology that potentially can be used as a part of solution.

3) Analysis and Design. This step describes the deep analysis of the problem, and design an appropriated solution that fulfill all the requirements.

4) Testing and Evaluation. This final step is the testing process. The proposed model is implemented and run in the testing environment. Survey conducted to the user (in this case are students) to evaluate how far this model effective to increase their knowledge, their practical understanding and motivation to be entrepreneur.

\section{PROPOSED SOLUTION}

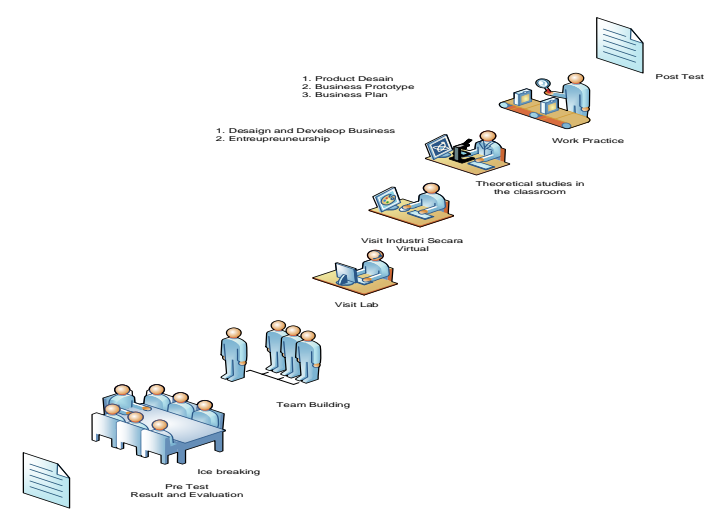

Figure 4 The Learning Model Business Incubator Based Technology Web 2.0
Based on literature review, there is a good approach that developed by Gibb (1999) and Gem (2002). This approach that consist of 4 steps will be adopted in this research. This adopted model will implemented using Web 2.0 technology and the system named as "Business Incubator Model Based on Web 2.0". This system will run as a part of the course in Faculty of Business and Management in Universitas Pendidikan Indonesia, Bandung, Indonesia. By this system, students will have integrated experiences in : (1) design and develop product, (2) identify tools and raw materials to produce a product, (3) managing all the process related to the product (Fig.4).

\section{RESUlT AND DISCUSSION}

Learning model developed in this study is a theoretical model of control recommended by Gibb (1999) and Gem (2002). Model of learning through the web 2.0 business incubator was originally developed in the learning business, with an emphasis on the ability of students to understand the teaching materials and improvement of students' business ideas, as the most educated entrepreneurial potential for development.

Business incubator models of the development consist of four (five) stages based on the theoretical model framework and the definitive model of development results, the discussion in this context, will focus on step by step in relation to the research focus.

The essence of clarifying issues and identifying the concept at this stage is to facilitate linkages between concepts and issues or problems that have been owned by the students with new information to be taught. Effort's excavation initial concept in this context is very important for student learning readiness condition (Bodner, 1960; Hasan, 1996). Un series of activities that we can see the sections below is un series of activities can be seen in the section below.

1. Creatifity program, during this phase the students practice various concepts to observe the business environment, subjects related to skills enhancement is, Introduction to business, introduction of Management, Mathematical Economics and Business Information Systems, for 2 times face to face representatives of the group to prepare an activity called entreupreuneur day, the main activity of this activity is preparing the product in the form of a virtual storefront. Every business project that entered the 4th meeting of each group of 4-5 students had the responsibility to identify and analyze opportunities that exist in the market space to be forwarded into a business idea. The subjects involved in this activity are, Microeconomics, business statistics, consumer behavior, financial management in order to form analytical and creative thinking at the end of the fourth meeting of business ideas presented was then drafted a simple business plan to be evaluated and followed at a later stage

2. Foundation Program, Divided into four stages, which are designed into the process of business formation, business ideas that have been presented subsequently developed into the idea of the aim of ensuring that the business idea 
is feasible and worth to be developed., Stage (1) At this stage each group's presentation in no more than 5 minutes to convince her idea, at the end of this activity, each student votes to choose the group with the best idea to be able to proceed to the next stage.. The criterion used in selecting the best is (a) the feasibility (b) the complexity of the (c) value added and (d) innovation. To elect his group must join the group winners. At this stage, students also are trained to improve their skills in recruiting employees, forming the organization, led the other co-equal and improve business performance. Stage (2) . Student group winners in the first-phase data collection in order to prove that his business idea is a brilliant idea. Method used in data collection is qualitative methods such as group discussions and in-depth interviews, each group was also required to look for some potential suppliers, estimated revenues, expenses and investment costs first. At the end of this stage, each group make a presentation. The group entered the category of 3 best proceed to the next stage. Each student will be asked to invest a virtual \$ 1 million. Virtual equity is useful to provide capital to the financial statements the value of the business is run. Stage (3) students grouped into three groups of 15 students who will enter the team "business plan" of each group of students must gather detailed information. Market surveys carried out at least on 50 potential customers. Data from the survey further analyzed the market to see the huge market potential. Each group was asked to make monetary projections and financial costs continued with the starters, the revelation of suppliers, and marketing plan. At this stage, the group made a presentation of business plans aimed to answer three questions : (1) why the idea of a business opportunity (2) how the idea can be executed (3) the projected level of profitability of the business. Each class represented a group to enter the stage (4). Step (4) of this each group was asked to make the organizational structure and the selection of top management consists of the CEO, CFO, VP of operations, VP of sales, VP of human resources, VP of communication, VP of Information technology and VP of community service.

3. Establishing entreupreuneurship program. The program starts with an idea-makers who registered their business concepts and present them before the evaluation team constituted in accordance with the business prospective entrepreneurs educated (college students), Evaluation includes (1) the added value the uniqueness of the business concept to offer (2) commercial feasibility (3) the scale of business, (4) the complexity of business (5) the possible market (6) actual funding (7) potential of the technology used. Once the project passes the selection then incubated in a web-based business incubator 2.0 supervised by Team Edupreuneur., After it was tested and found worthy to run the next step searching for potential investors to fund the business, the next entry in the incubator for hatching program.

4. Hatchery program The program is implemented with the assistance intensify together Edupreuneur Team. The students formulate operational plans include marketing, finance, legal, manufacturing, process operations, technology and human resources, in this case Edupreuneur Team helped legality (the formation of business entities) as well as taxation. Every step of the company's operations that have been formulated previously evaluated its implementation for further analysis sought settlement of any weaknesses that occur in implementation.

By The four stages of the 174 students who participated through a business incubator based, Web 2.0 to reach Program Hatching only 43 students or $25 \%$, and as many as 95 students can achieve entrepreneurial programs or as much as $55 \%$. These findings indicate that the stages to be the Entrepreneurial learning model can be realized through a web-based business incubators 2.0.

\section{CONCLUDING REMARKS}

In this research, one model of entrepreneurship was proposed. This model is a business incubator based on Web 2.0 technology. It was implemented and evaluated. The evaluation result shows that this model can increase understanding, experience, and motivation to be entrepreneur

\section{REFERENCES}

[1] Mc Clelland David. C, Amanson John. W Clark Russel A, Lowel Edgar L. (1976), The Achievement Motive, Oxford Iruington

[2] Mulia Ginting Munthe (2012), Wirausaha muda. (http://www.bisnis.com/articles/wirausaha-muda)

[3] Chou. CM, Shen CH, Lee YJ, (2007), A Study on Enterprise, Employment Terms and Competencies for Technological and Vocational School Graduates Taiwan, Word Transaction on Engineering and Technology Education, pp. 301-308

[4] D.A. Kolb 1984 Experiential learning: experience as the source of learning and development. Prentice Hall, Englewood Cliffs, NJ

[5] Fayolle, Alain and gailly (2008), From Craft To Science ; teaching Modelsn and learning process in entreupreuneurship education "Journal Of europian Industrial training Vol 32 no 7 PP 569-593

[6] Heinonen J and Sari-Anne Poikkijoki (2006), An Entreupreuneurial Directed approach to Entreupreuneurship Education Mission Immposible 'The Journal of Management Development Vol 25 (1) 8094

[7] Heinonen, Jarna. (2007). An Entrepreneurial-directed Approach to Teaching Corporate Entrepreneurship at University Level. Education + Training, 49 (4): $310-324$

[8] Gibb, A (1993) Small Business Development in Central and Eastern Europe- Opportunity for a Rethink ? Journal of Business Venturing vol 8 (6) $461-487$

[9] Gibb A, (1999), Can we Build Effective Entreupreuneurship Through management Development "Journal of general manager vol 24 (4) 1-21 